'Under the Mediterranean'The Honor Frost Foundation Conference on Mediterranean Maritime Archaeology 20 th -23 rd October 2017 Short Report Series

doi: https://doi.org/10.33583/utm2020.10

(C) 2020 The Author

\title{
A Strategic Protection Scheme for the Submerged Bronze Age Town at Pavlopetri
}

\section{Barbara Euser}

President, Greek Chapter of Alliance for the Restoration of Cultural Heritage (ARCH), Neapolis, Greece

The Bronze Age site of Pavlopetri is the oldest submerged city in the world, with indications also of earlier Neolithic occupation. At eight hectares, it is the largest area of Bronze Age ruins on mainland Greece. The fragile ruins are threatened by pollution, rotting posidonia weed, sand movement, nearby tankers, tourist boats anchoring on the site and casual tourist pilfering. Since the first mapping in 1968, the ruins have been mapped again to modern standards during 2009-2012 using Total Station and AUVs. The condition of the ruins has been monitored continuously since 2008 . The ruins are degrading more rapidly than expected. Since 2014, the Greek Chapter of the Alliance for the Restoration of Cultural Heritage (ARCH) has worked within the local community and up and down the political-bureaucratic spectrum to preserve and protect Pavlopetri, including work with UNESCO, EU, Greek government agencies, World Monuments Fund, Greek Coastguard, and local schools. We have made powerful contacts locally and at every level of academic and European and Greek politics. We effectively educated key players and used negotiation and diplomacy to gain support and advance our goal. Greek ARCH has developed a strategic program of protection. The site must be protected for future archaeological research, and for current public enjoyment and access. This paper describes the underwater work on site and the range of bodies that have to be engaged, permits and approvals required, maintaining local 
commitment and pride, as well as the pragmatic design of improved public access. Can any underwater damage to the ruins at the site be legitimately repaired? Can sponsors be found to fund protection? The necessary components of protection are not yet all in place, and much work is still needed. The Pavlopetri campaign serves as a useful example for community engagement and activism to protect underwater cultural heritage sites elsewhere in the Mediterranean.

Pavlopetri is located at the north-western end of Vatika Bay, near the southern end of the eastern finger of the Peloponnese in Lakonia, Greece. Pavlopetri dates from the Early Bronze Age, about 3500 BCE, or 5500 years ago. The inhabitants were accomplished navigators and traded throughout the eastern Mediterranean. The city flourished for 2000 years, then gradually sank into the sea. Thus, nothing was built on top of it.

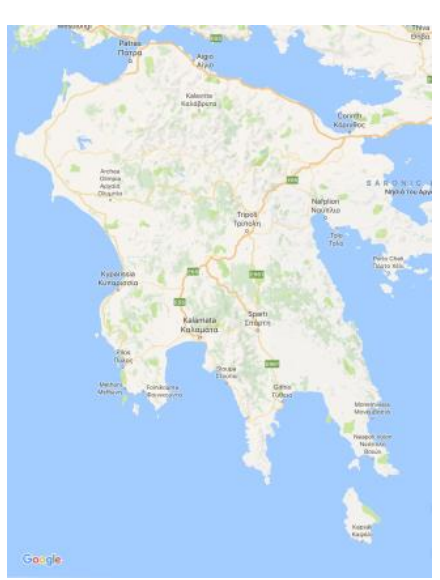

Google Maps image

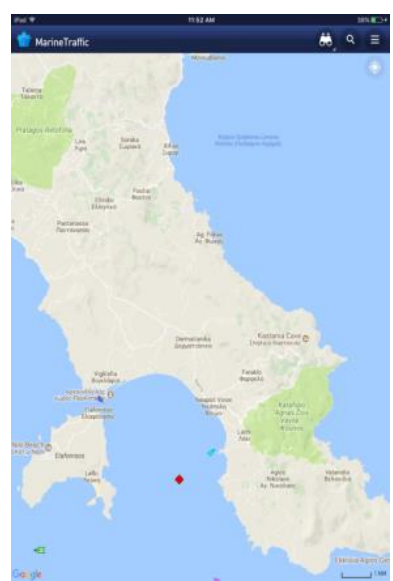

MarineTraffic.com screenshot
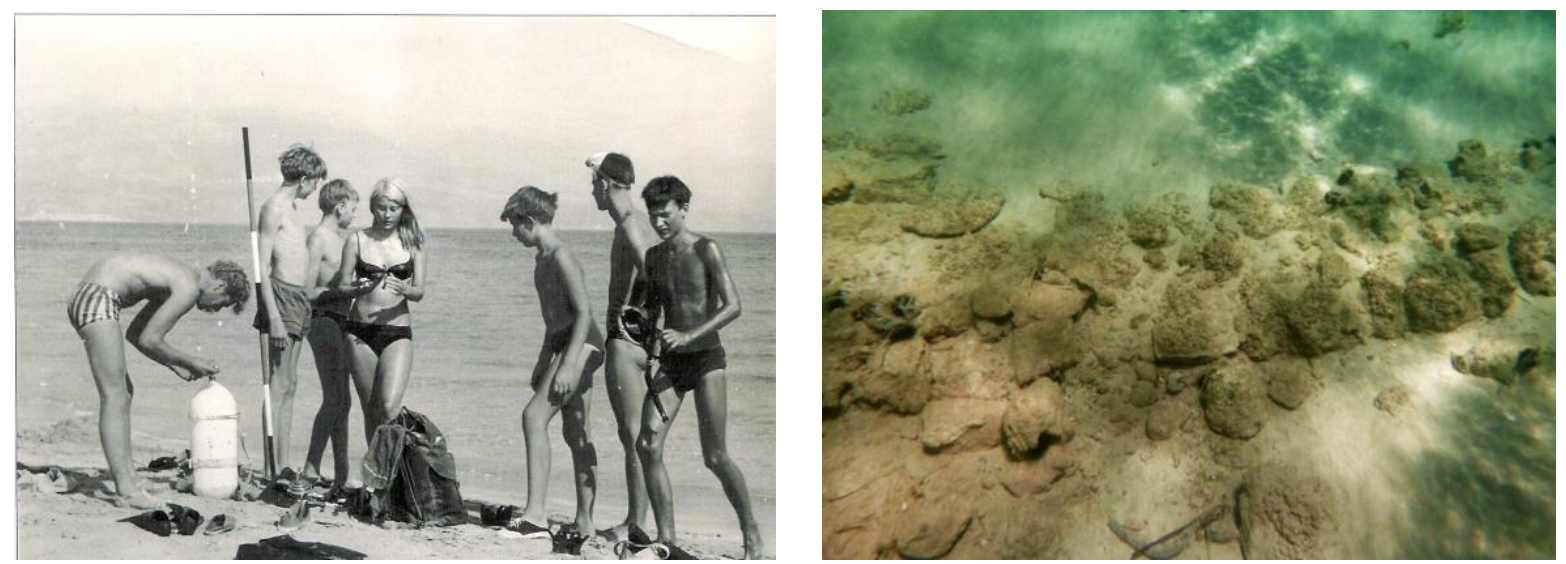

Photo courtesy of Nic Flemming. Photo of wall foundations at Pavlopetri courtesy of Barbara Euser 
Pavlopetri was discovered by Dr Nic Flemming in 1967. A Cambridge expedition in 1968, led by Dr Anthony Harding, further explored and mapped the site.Foundations of houses, courtyards, streets, and large buildings are easily visible two to three meters underwater.
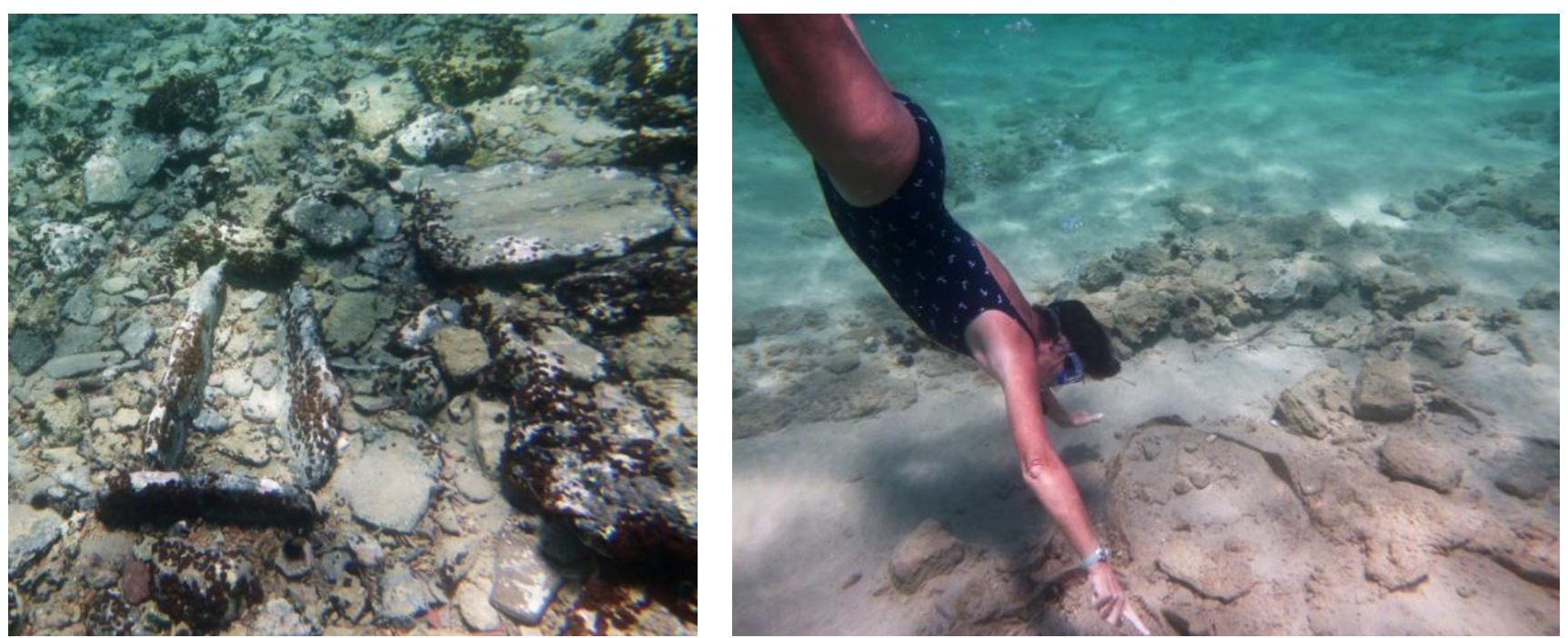

Photo of cist grave at Pavlopetri courtesy of Barbara Euser

Photo showing edges of broken large clay jar_-pithos—at Pavlopetri courtesy of Connie Burke

\section{Recent excavations at Pavlopetri}

The Pavlopetri site was left alone from 1968 until 2009, when the University of Nottingham obtained a five-year permit, from 2009 to 2014, to mount an international expedition to map and excavate Pavlopetri in co-operation with the Greek Ministry of Culture. The expedition was led by Jon Henderson and Chrysanthy Gallou of the University of Nottingham and Elias Spondilis of the Ephorate of Underwater Antiquities. The city covers at least eight hectares, according to mapping that was done during the scientific exploration of 2010.

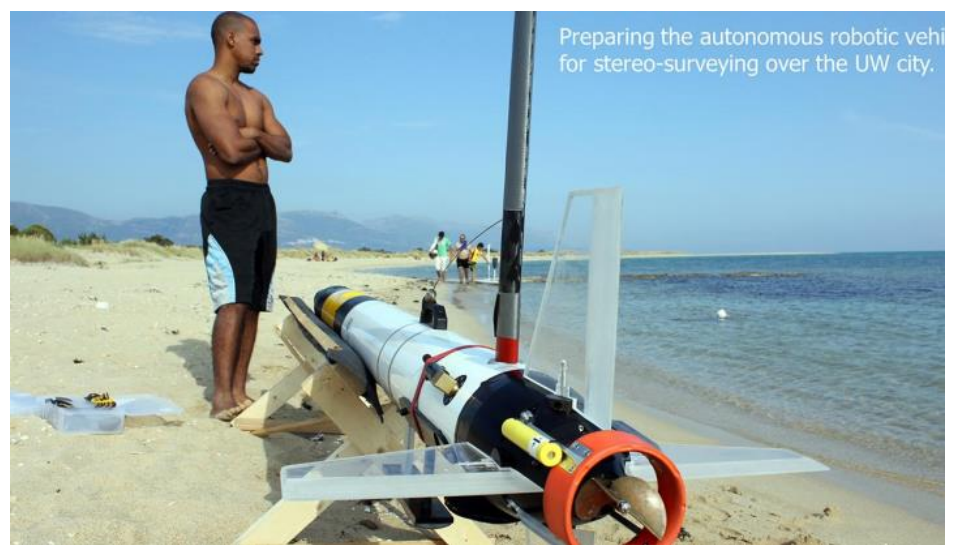

Photo of autonomous robotic vehicle for stereo mapping at Pavlopetri courtesy of Oscar Pizarro 


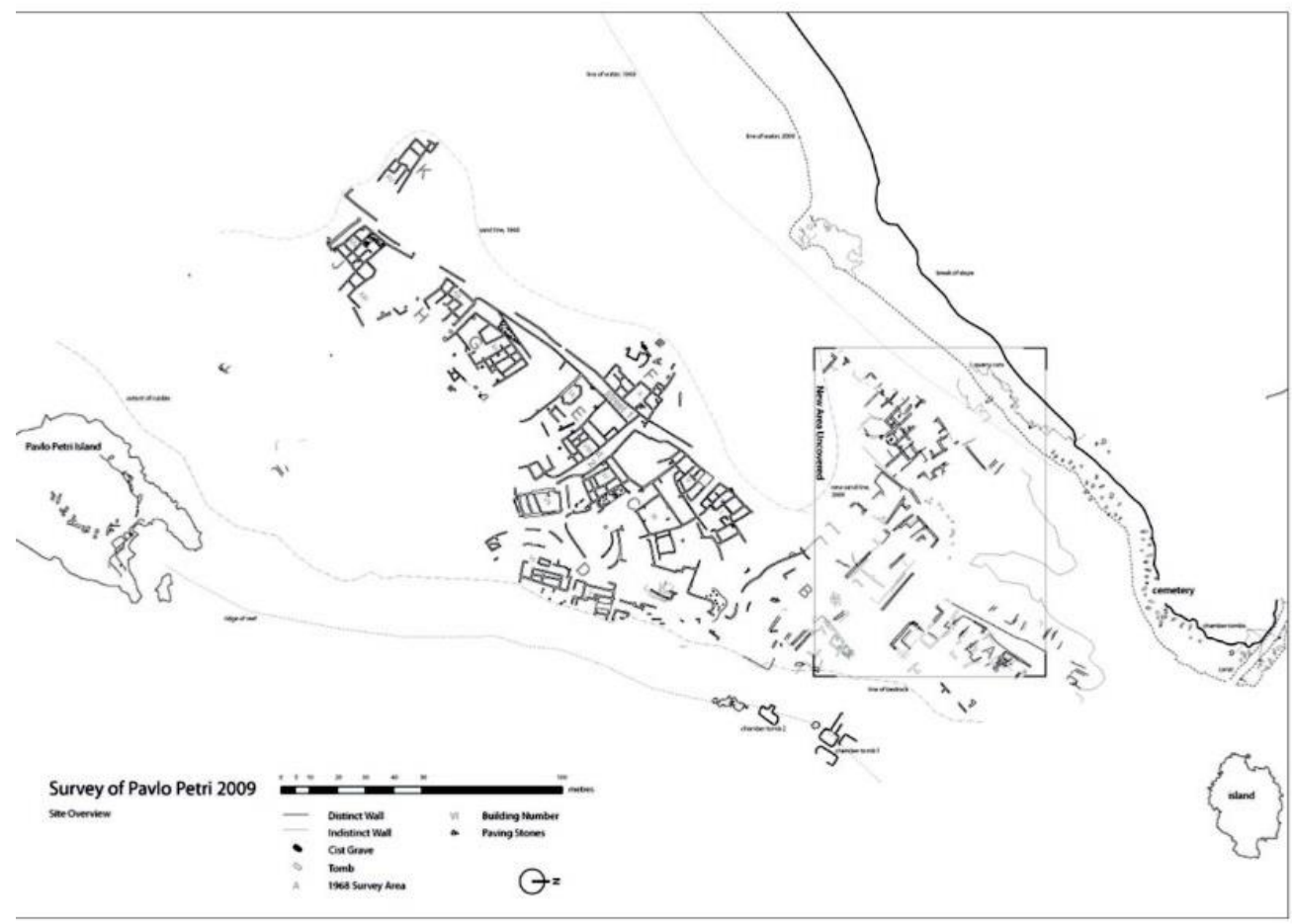

Map published in the International Journal of Nautical Archaeology, v.42, no.2 2013 Sept, p.243 (14), Henderson, Jon; Pizarro, Oscar; Johnson-Roberson, Matthew; Mahon, Ian.

The arrival of the scientists in the summer of 2009 piqued local interest. The local mayor provided a warm reception. Friends and I visited the scientists at their base camp and found them happy to share information and educate us about the importance of the underwater city. When asked about what problems Pavlopetri faces, the scientists said there were three main threats: pollution, shifting sediments, and disruption of the site itself by looting and small boat anchoring. Local residents took action: In 2013, a group of 50 locals petitioned the Special Representative of the Environment, complaining about the pollution of Vatika Bay caused by large commercial ships that anchor there. The response of the Special Representative of the Environment was to send the petition to the local Coast Guard. Because there is no Special Port Regulation that governs anchoring in Vatika Bay, it is allowed at the discretion of the local Coast Guard - which was, in this case, the cause of the problem. Nothing happened.

\section{International Organizations}

In May 2014, I invited Dr Cheryl Benard, President of the Alliance for the Restoration of Cultural Heritage, with the acronym of $\mathrm{ARCH}$, to visit Neapolis, hoping ARCH might adopt Pavlopetri as one of its projects. Dr Benard snorkeled over Pavlopetri and met with local people, including the editor of the monthly newspaper, Ta Vatika. The editor had been publishing articles about Pavlopetri since 2009. As a result of her visit, Dr Benard 
recommended to the Board of $\mathrm{ARCH}$ that they accept Pavlopetri as one of their endangered cultural heritage sites. ARCH International suggested we form a local chapter, which is called the Greek Chapter of ARCH. I am its President. This alliance with an international non-governmental organization is key to the progress we have made to date.

ARCH immediately suggested that the local chapter nominate Pavlopetri to the World Monuments Fund Watch list for 2016-2018. We worked hard on the application, which was due in March 2015. In October 2015, we were delighted when Pavlopetri was designated to the 2016-2018 World Monuments Fund Watch. This helped raise international awareness of our endangered cultural heritage site and gave ARCH access to potential funding.

\section{Media Attention}

Whenever something important like this happens, it must be reported to the public. Fortunately, the Greek Chapter of ARCH has the support of the local newspaper and the local radio station. Social media is extremely important in publicizing causes. The Greek Chapter of ARCH set up a website at pavlopetri.org and a Greek Chapter of ARCH Facebook page, which appears as a feed on the website. ARCH International has a website, Facebook page and Instagram page. ARCH maintains a media contact list, to which the Greek Chapter of ARCH send its press releases.

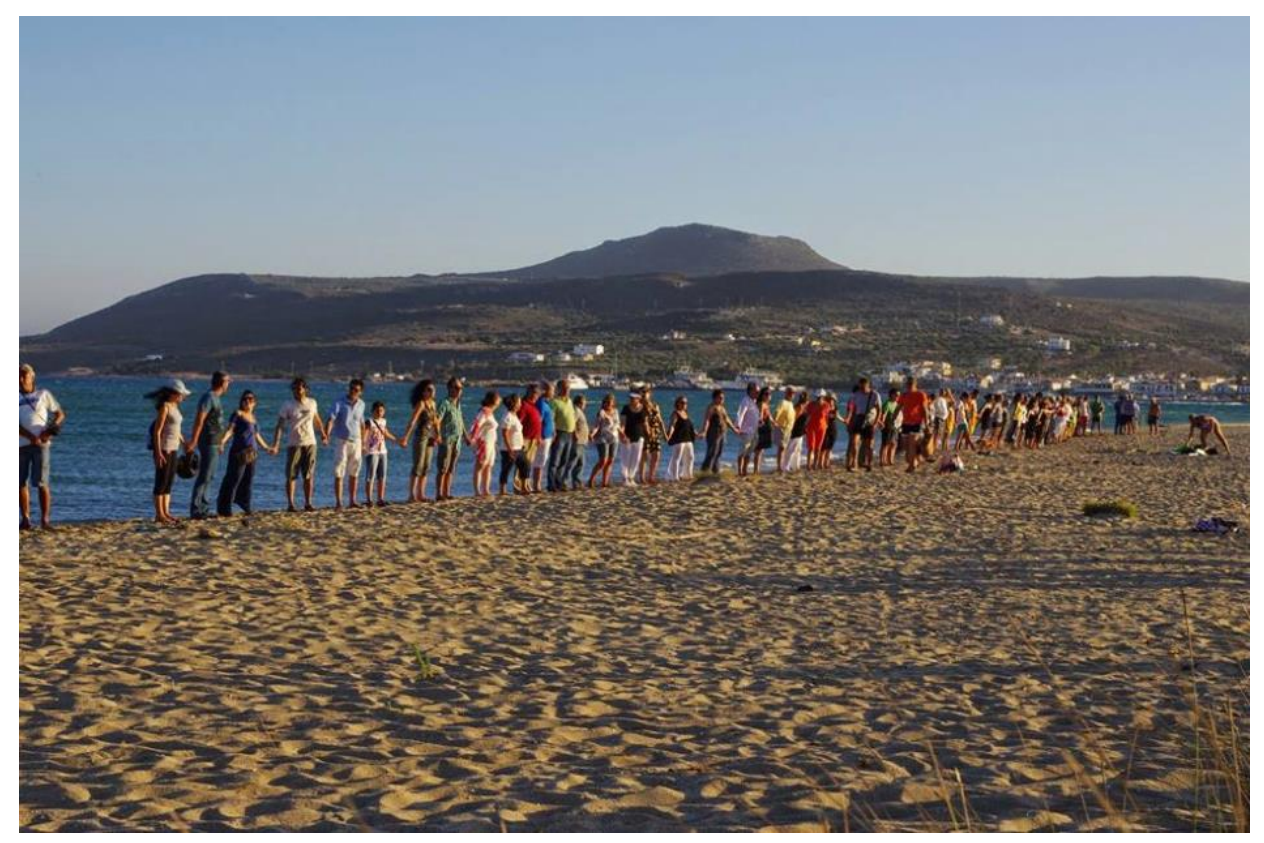

Photo courtesy of Franscesca Roma 
With an eye to media attention, in August 2014, a gathering was held at Pavlopetri to create a human chain, symbolically protecting the archeological site. Dozens of swimmers circled the site and over a hundred more joined on land. This is one of our most powerful images.

\section{Casting a Wide Net}

To accomplish anything, we needed to develop a network of contacts. To do this, in the Autumn of 2014, Dr Connie Burke, an active member of the Greek Chapter of $\mathrm{ARCH}$, and I met with the Cultural Attache at the United States Embassy and an official at the Ministry of Tourism. Because Pavlopetri is an underwater archeological site, we also hoped to develop contacts focused on the marine environment. We met with representatives of the monk seal protection organization Mom; the loggerhead turtle protection organization ARCHELON; MEDASSET, a marine conservation organization; and representatives of the World Wildlife Federation. Peter Nicolaides of the Aegean Dive Center in Paros was particularly helpful, representing Pavlopetri directly to the then Minister of Tourism.

\section{Legal Remedies}

To explore legal remedies, ARCH suggested the Greek Chapter of ARCH contact PILNet, the Public Interest Law Network. PILNet is an NGO that matches lawyers who volunteer to do pro bono work with other NGO's. The Greek Chapter of ARCH submitted a description of Pavlopetri and the problems it faces and PILNet found an Athens law firm that agreed to help us. Because we wanted to seek local remedies before going to international authorities, we agreed that the law firm would formulate a question for an MP to present to the Vouli, the Greek Parliament, to which the Greek government is supposed to respond. The firm did this, and the question was raised, citing the problems caused to the marine environment and the archeological site by the anchoring of freighters and tankers in Vatika Bay. There was no direct government response to the question, but an indirect response from the Ministry of Maritime Affairs was to propose a Special Port Regulation for Vatika Bay that would allow an unlimited number of large commercial ships to anchor there.

This proposed Special Port Regulation was anathema not only to the Greek Chapter of ARCH, but also to all the businessmen and women surrounding Vatika Bay who make their living in the coastal tourist economy. Hoteliers, restauranteurs, owners of bars and cafes, souvenir shops, as well as environmentalists, opposed the proposed regulation. The Greek Chapter of ARCH met with representatives of the Ministry of Maritime Affairs and the Ministry of Tourism and participated in local public hearings. The proposal was defeated, but only temporarily. 
After preparing the question for the Greek Parliament, the Athens law firm declined to do more work for the Greek Chapter of ARCH. We went back to PILNet, having failed on the local front, and asked for help on the international front. PILNet found a barrister in London interested in helping us. He drafted an extensive memorandum of actions that would be available in the European Union and the United Nations. We collected information needed to file a Petition with the EU Parliament, focusing on the devastating damage to Posidonia Oceanica caused by ships that anchor in Vatika Bay, as documented in two studies performed by the Hellenic Center for Marine Research, under the direction of Dr Dimitris Sakellariou. ARCH also collected the information required to file a Complaint with the UN Special Rapporteur on Cultural Rights. Our British barrister drafted the actual documents. The EU Petition was filed in August 2016, and the UN Complaint in January 2017. To date, we have had no feedback regarding the Petition or the Complaint. The problems caused by the freighters and oil tankers continue to be a challenge today.

\section{Regional Contacts}

Continuing our efforts to preserve, protect and promote Pavlopetri, the Greek Chapter of ARCH met with local officials of Elafonisos Island. They informed us of an existing agreement between the Municipality of Elafonisos, the Region of the Peloponnese and the Ministry of Culture with three main provisions: 1) buoys to surround the perimeter of the archeological site of Pavlopetri, to make it clear that small craft and fishing boats should not cross the site or anchor there; 2) publication of brochures to educate locals and tourists about the importance of Pavlopetri; 3) construction of an informational kiosk to be built near the site. The Greek Chapter of ARCH sees itself as a supporter of local initiatives. We offered to raise funds so the Municipality of Elafonisos could carry out the provisions of the agreement.

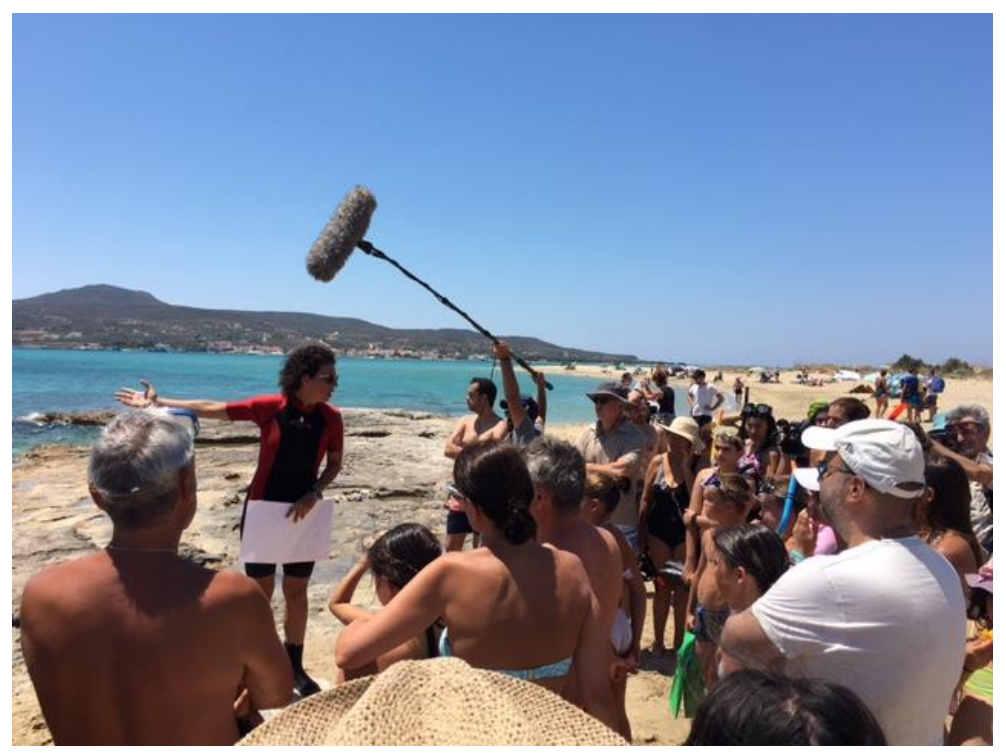

Photo of Despoina Koutsoumpa previewing snorkeling tour courtesy of Dimitris Delacovias 
As part of the World Monuments Fund Watch designation, the Greek Chapter of ARCH agreed to put on an annual Pavlopetri Watch Day celebration. In July 2016, the first Pavlopetri Watch Day included snorkeling tours led by Despoina Koutsoumpa of the Ministry of Culture, presentations by Dr Flemming and Prof. Delavorias of the Benaki Museum, a film screening, games for children, a photo exhibition, and support for the Elafonisos agreement. This included a full-color brochure printed by ARCH.

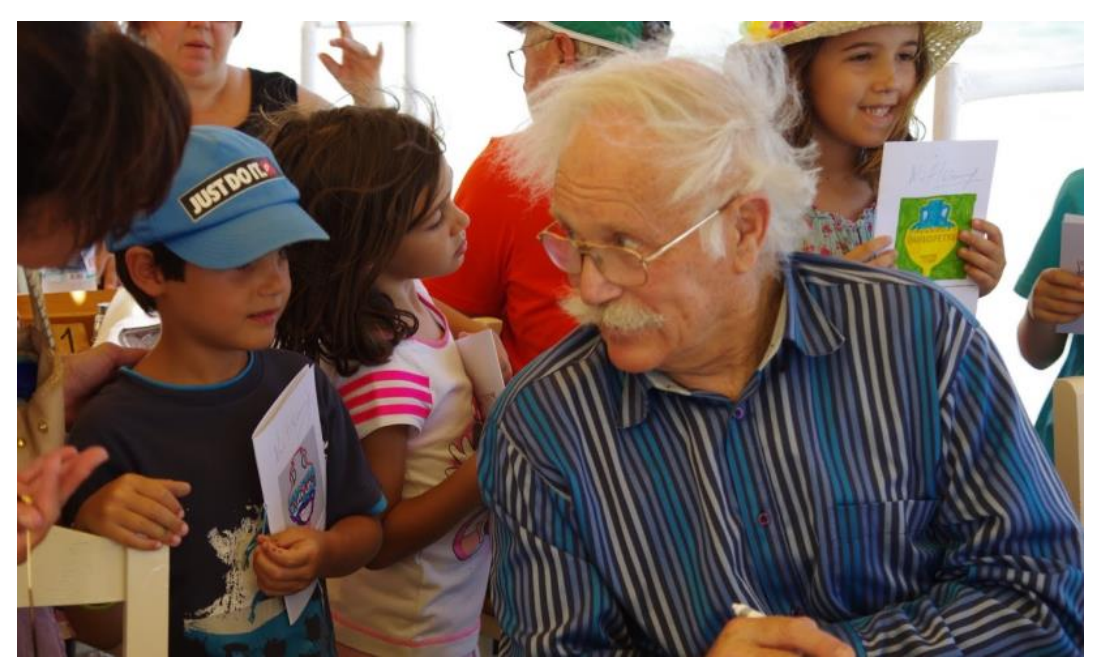

Photo of Nic Flemming with children on Elafonisos Island courtesy of Dimitris Delacovias

The second item in the Elafonisos agreement was the buoys. ARCH raised money from local donors and donated eleven buoys to the Ministry of Culture, which were placed around the perimeter of the Pavlopetri archaeological site. 


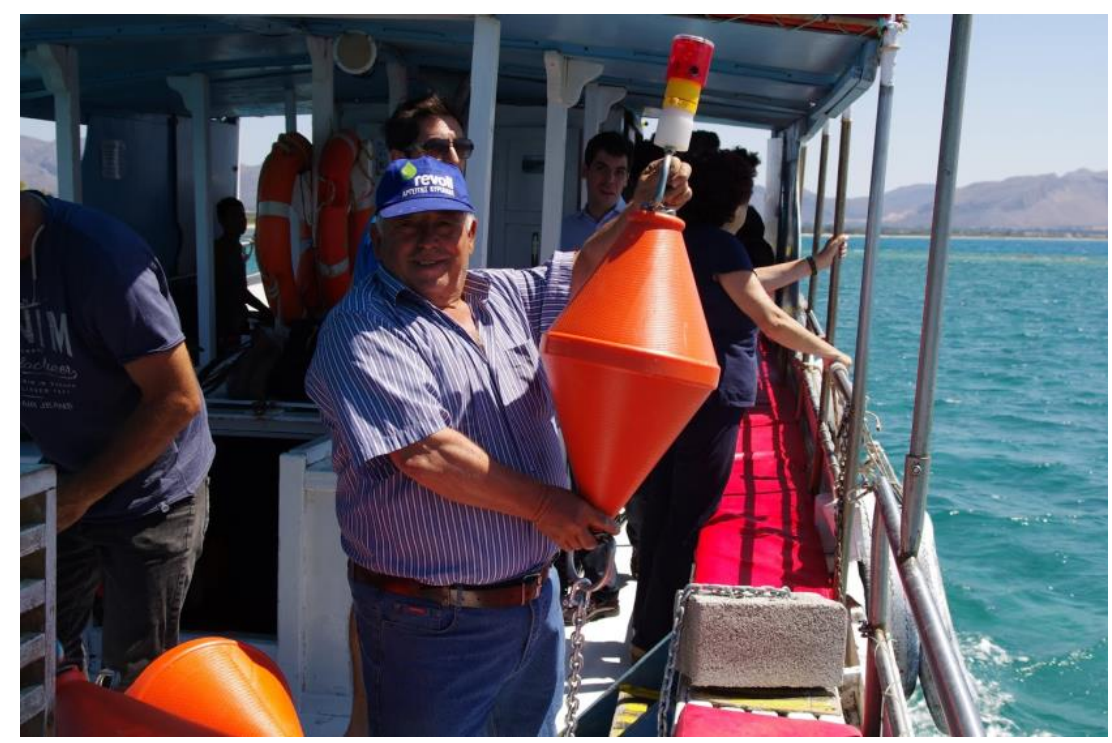

Photo distributing buoys around Pavlopetri, July 2016, courtesy of Dimitris Delacovias

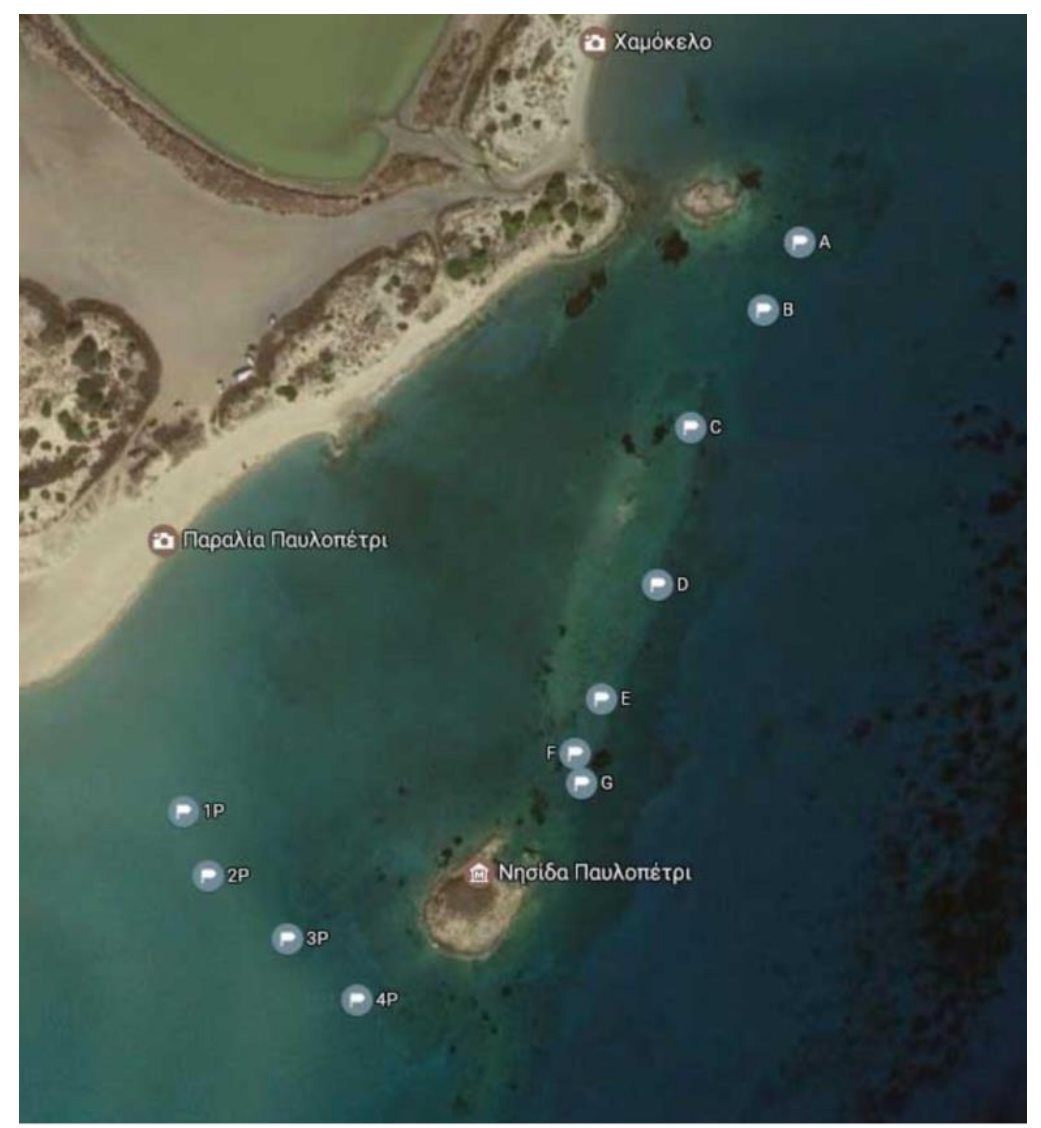

Image of buoys placed around Pavlopetri courtesy of Ilias Kroupis

The third item in the agreement, an information kiosk, is still pending. 


\section{International Meetings}

In September 2016, Dr Burke and I attended the meeting at UNESCO in Paris on the 2001 Convention on the Preservation of Underwater Cultural Heritage. This provided an excellent opportunity to meet with international experts on underwater sites. We also met with the Greek delegation for UNESCO regarding ratification of the 2001 Convention.

\section{A Management Plan}

Dr Mechtild Rossler, Director of the Division for Heritage and the UNESCO World Heritage Centre, who chaired the UNESCO meeting, provided an introduction to Dr Elena Korka, Director General of Antiquities and Cultural Heritage at the Greek Ministry of Culture. Dr Burke and I met with Dr Korka in Athens in November 2016 and discussed Pavlopetri's situation. We asked about Greek ratification of the 2001 Convention. We addressed the information kiosk in the Elafonisos Agreement, which should include a designated parking area and a boardwalk to protect the fragile ecosystem of the sand dunes on the beach. Dr Korka agreed that a Management Plan should be prepared. She chaired a meeting in December 2016, at which a general consensus was reached -- and then nothing further happened.

The Greek Chapter of ARCH continued to expand its efforts to bring international attention to Pavlopetri. In July 2016, the Cetacean and Pelagic Institute spearheaded an effort to have Vatika Bay and the surrounding Myrtoon Sea designated as a Natura 2000 Marine Area, based on the presence of dolphins, whales, monk seals, loggerhead turtles, and other EU-protected species. ARCH actively supported this effort. As the Natura 2000 Marine area proposal foundered, the Marine Conservation Institute in Washington, DC, suggested proposing Vatika Bay and the Myrtoon Sea as a Mission Blue Hope Spot. The prestigious international marine conservation organization Mission Blue designates endangered marine areas as Hope Spots if they meet certain criteria. Working with the Cetacean and Pelagic Institute and $\mathrm{ARCH}$, Mission Blue designated Vatika Bay and the Myrtoon Sea as the first Hope Spot in Greece in April 2017. Unfortunately, the Greek government subsequently decided not to designate the area as a Natura 2000 Marine Area. 


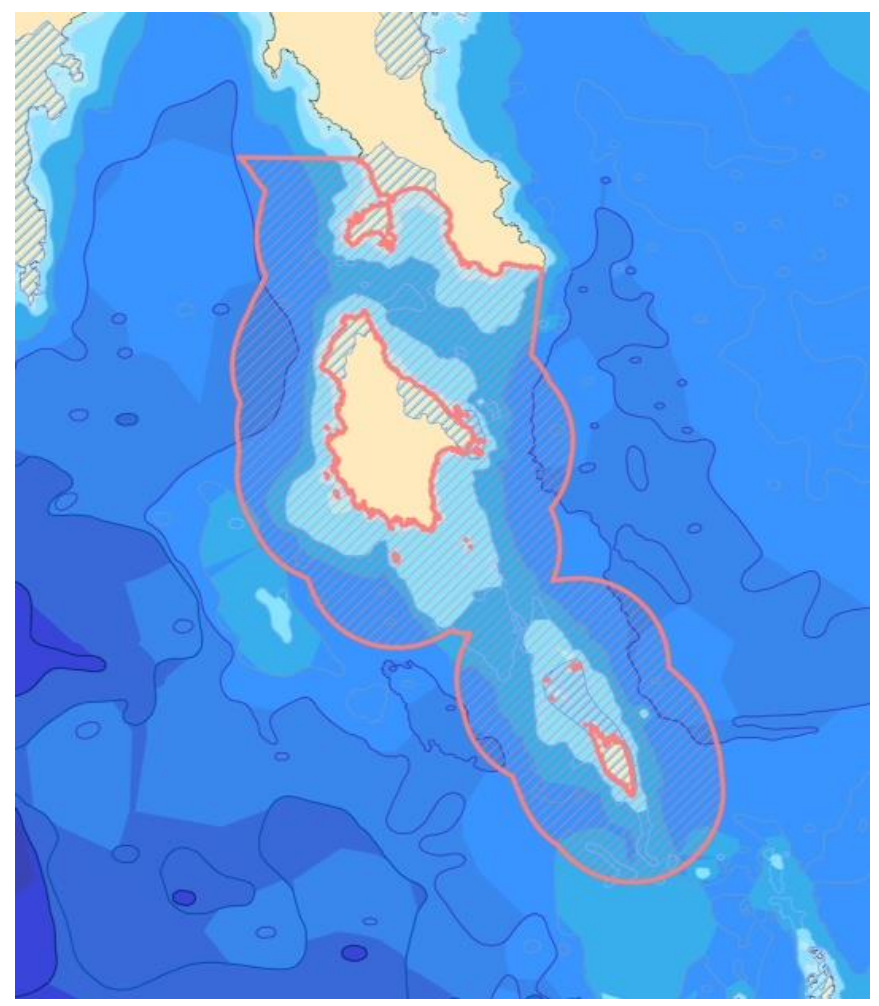

Image of the proposed Natura 2000 Marine Area and the Mission Blue

Vatika Bay/Myrtoon Sea Hope Spot courtesy of Mission Blue

\section{UNESCO at Pavlopetri Watch Day 2017}

In July 2017, the Greek Chapter of ARCH organized its second annual Pavlopetri Watch Day. Dr Mechtild Rossler agreed to be the keynote speaker and her trip became an official UNESCO Mission. She addressed the importance of the 2001 Convention and why Greece should ratify it. Joining Dr Rossler on the podium, were Dr Elena Korka of the Ministry of Culture and Dr Aggeliki Simosi, Director of the Ephorate of Underwater Antiquities. The Governor of the Peloponnese Petros Tatoulis and MP Stavros Arachovitis also attended. Substantive progress that emerged from the event included the Governor's support for preparation of a Management Plan and official government recognition of Pavlopetri. Dr Korka said the Greek government is moving towards ratification of UNESCO's 2001 Convention.

In its efforts to preserve, protect, and promote Pavlopetri, ARCH and the Greek Chapter of ARCH continue to work with local, regional, and Ministerial-level officials, networking with marine conservation organizations, and at the same time, seeking recognition for Pavlopetri at the international level. 
Additional note: The geographical coordinates of the Pavlopetri archeological site were published in the official Greek government FEK on February 1, 2018. This ensures a three-kilometer buffer zone around Pavlopetri in which no anchoring or fishing is allowed. We have observed that since the co-ordinates were published, fewer ships are anchoring in Vatika Bay, and for shorter periods of time. This is a benefit to our Hope Spot and the entire marine environment. 